\title{
Keefektifan Hubungan Tingkat Profitabilitas Perusahaan terhadap Harga Saham
}

\author{
Fetri Setyo Liyundira \\ STIE Widya Gama Lumajang \\ Liyundira90@gmail.com
}

https://doi.org/10.30741/adv.v3i2.471

\section{N F O A R T I K E L}

Tanggal masuk :

10 November 2019

Tanggal Revisi :

12 Desember 2019

Tanggal Diterima :

31 Desember 2019

\section{A B S T R A K}

Keefektifan Hubungan Tingkat Profitabilitas Perusahaan terhadap Harga Saham. Pasar modal menjadi dan memiliki fungsi ekonomi terutama dalam perekenomian Indonesia, dua belah pihak yaitu investor dan issuer yang menyampaikan beberapa hal yang difasilitasi oleh pasar modal yang menyajikan sarana atau wahana. Dalam penelitian dibahas tentang pengaruh Rasio profitabilitas yang digunakan yaitu indikator Return On Investment (ROI) dan Earning Per Share (EPS) kepada nilai saham. Sampel yang digunakan ada 56 perusahaan yang sudah masuk dalam berbagai kriteria kemudian diuji dengan menggunakan SPPS dengan menguji asumsi klasik terlebih dahulu untuk semua variabel, setelah diuji asumsi klasik maka dilakukan Uji Statistik untuk mengetahui hubungan sebab dan akibatnya. Hasil dari uji statistik dapat disimpulkan bahwa investor mempertimbangkan berbagai hal dan salah satunya adalah melihat nilai Return On Investment (ROI). Laba akan dihasilkan dengan penggunaan asset perusahaan yang maksimal sehingga nilai perusahaan dapat meningkat, sejalan dengan harga saham yang meningkat untuk mendapat respon yang baik dari investor. Selain laba yang dihasilkan, investor juga bermanfaat bagi investor. Salah satunya juga melihat keuntungan karena besar atau kecilnya akan menunjukkan kemampuan perusahaan untuk membagikan deviden ke investor. Dari sinilah tampak ketika terjadi transaksi maka investor akan menerima deviden akan semakin tinggi maka terlihat keberhasilan suatu perusahaan.

Kata Kunci : ROI, EPS, dan Harga Saham 
prices to get a good response from investors. In addition to the profits generated, investors also benefit investors. It is wrong to only see profits because big or small will show the company's ability to distribute dividends to investors. From this it appears that a complicated transaction occurs, investors will receive dividends will be higher, it is seen getting a company.

Keywords: ROI, EPS, and Stock Prices

\section{PENDAHULUAN}

Dewasa ini digital teknologi sangat mempengaruhi dan merubah pola hidup rakyat khususnya di Indonesia, dari perilaku yang konvensional menjadi sangat mudah dengan efisien, hemat dan cepat diberbagai layanan investasi di pasar modal. Oleh karena itu, ramainya entitas yang menggunakan sistem financial technology dirasakan peluang untuk mengembangkan industri pasar modal dalam memberikan kemanfaatan pelayanan bagi masyarakat. Pasar modal yang menjadi dan memiliki fungsi ekonomi terutama dalam perekenomian Indonesia, dengan adanya pasar modal yang mempunyai kepentingan atau yang mempunyai kelebihan dana (investor) bisa bertemu langsung pada pihak yang memerlukan modal (issuer) karena pasar modal ini bias dikatakan sebagai perantara atau fasilitas bagi kedua belah pihak ini.

Pembisnis lebih tertarik dalam melakukan penanaman investasi pasar modal tentunya hal ini menjadi dasar dari perekonomian di Indonesia, khususnya di Bursa Efek Indonesia (BEI) yang terlihat jumlah investornya semakin hari semakin meningkat untuk tiap tahunnya. Menteri Keuangan Sri Mulyani menyampaikan dalam Kompas.com bahwa di pasar modal untuk jumlah investor dengan berbagai macam investor melingkupi investor saham, reksadana dan surat utang sudah menggapai 2,48 juta investor yang dari tahun 2017 naik hingga 50\% yakni sejumlah 1,62 juta investor. Selain itu masih tercatat 55 entitas yang tercatat sebagai saham baru dan aktivitas pencatatan saham baru (IPO Saham) terunggul di antara bursa-bursa di wilayah Asia Tenggara dan menjadi rangking ke 71 di dunia. Hingga saat ini entitas yang tercatat saham di Bursa Efek Indonesia sudah mencapai 668 entitas.

PT. BEI menyampaikan bahwa investor pasar modal Indonesia waktu ini yaitu mayoritas golongan milenial yang berusia dibawah 30 tahun yakni mencapai sekitar 40,33 persen jelas Direktur Utama PT. BEI. Investor pasar modal Indonesia banyak dari berbagai kalangan dimulai dengan kategori usia, kategori pendidikan, pegawai swasta. Saham merupakan sebuah instrumen yang berada di pasar modal yang diminati oleh investor, perusahaan transportasi digolongkan sebagai sektor perusahaan yang diminati investor di Indonesia, karena tergolong perusahaan yang cukup besar. Pada tahun 2015 perusahaan transportasi mengalami keterpurukan dan mengalami fluktuasi dalam pertumbuhannya, sehingga membuat para investor sebelum mengambil keputusannya akan melakukan penilaian terhadap saham yang akan dipilih agar menghasilkan keuntungan yang di harapkan.

Untuk melakukan sebuah analisis harga saham dapat dilakukan dengan berbagai cara yang bertujuan untuk mengetahui berbagai jenis dan bidang perusahaan dalam berinvestasi agar lebih mudah mengetahui saham dengan nilai return yang tinggi dan meminimalisir tingkat resiko dalam berinvestasi. Analisis yang digunakan untuk mengetahui layak untuk dibeli atau tidaknya harga saham untuk dibeli investor terdapat 2 (dua) analisis yaitu analisis secara fudamental dan analisis tenikal. Hermuningsih (2012:4) mendefinisikan ada 2 (dua) analisis yang digunakan yaitu Analisis fundamental adalah saham mempunyai nilai seharusnya (intrinsik). Pengukuran analisis ini yakni perbandingan nilai instriksi sebuah saham dengan nilai pasarnya untuk mengetahui nilai pasar saham telah bisa dikatakan dapat menunjukkan nilai intrinsik. Sedangkan analisis teknikal yaiu sebuah pengukuran yang digunakan untuk mengetahui pergerakan saham atau surat berharga untuk melihat grafik harga dan volume pada periode sebelumnya. 
Harga saham merupakan faktor penting bagi para investor dan menjadi hal yang perlu untuk diperhatikan ketika berinvestasi karena dapat dijadikan acuan untuk menentukan nilai perusahaan. Apabila perusahaan mempunyai kinerja yang bagus maka investor hendak mempertimbangkan kembali dalam membeli saham pada emiten tersebut. Indikator penting yang berpengaruh terhadap harga saham salah satunya rasio profitabilitas. Menurut Fahmi (2014: 82) rasio profitabiltas sering digunakan untuk mengukur seberapa efektif manajemen secara keseluruhan yang bertujuan melihat perolehan antara penjualan ataupun investasi untuk mengukur tingkat pendapatan. Salah satu rasio profitabilitas yakni Return On Investment (ROI) dan Earnings Per Share (EPS). ROI adalah parameter yang digunakan oleh investor demi mengevaluasi efisiensi suatu investasi dilihat dari seberapa besar kas yang terdapat dalam aktiva perusahaan dalam operasionalnya, dengan tujuan untuk memperoleh laba. Menurut (Isyani, 2015) untuk melihat besarnya bisa kita peroleh dari pertumbuhan perusahaan dan hasil perhitungan Earnings Per Share (EPS) dapat dijadikan investor sebagai bahan pertimbangan.

ROI dapat dijadikan sebagai pengukuran dalam ikhtisar keuangan karena bersifat komprehensif. Tingginya rasio menandakan semakin baik keadaan perusahaan. ROI menjadi salah satu tolak ukur untuk menentukan apakah kinerja keuangan entitas baik atau tidak, dimana hal ini dapat digunakan untuk memperoleh keuntungan para pemegang saham sehingga mendorong untuk meningkatkan harga saham. EPS juga diutamakan dalam analisis laporan keuangan perusahaan karena harga saham yang berubah akan berhubungan dengan earnings per share. Menurut Fahrudin dan Darmadji (2012:154) bahwa untuk mengetahui keberhasilan perusahaan, calon investor banyak menggunakan EPS untuk dijadikan sebagai salah satu indikator.

Return on Investment (ROI) adalah rasio yang difungsikan guna menakar kapasitas entitas dari profitabilitas yang dhasilkan oleh entitas yang bersumber dari dana pada aset entitas yang difungsikan kegiatan operasional entitas (Munawir, 2007:89). Hal ini menunjukkan bahwa komitmen sebuah entitas dapat dipertanggungjawabkan dalam pengelolaan usahanya dalam menghasilkan laba. Maka, nilai ROI yang tinggi membutikkan semakin baik pula kinerja suatu entitas tersebut. Hal ini tentu menjadi sebuah pertimbangan bagi para investor dalam berinvestasi, dengan nilai ROI yang semakin tinggi menunjukkan perusahaan itu aman dan ada pengharapan dalam memperoleh laba. Ketertarikan investor akan semakin tinggi untuk membeli sebagian sahamnya. Pada dasarnya harga suatu saham di tentukan dengan kondisi pasar yang ditentukan dari taraf permintaan dan penawaran saham.

Tejaningtyas (2016) melakukan penelitian tentang Dampak Rasio Profitabilitas kepada nilai saham pada entitas Real Estate dan Property yang tercatat di BEI tahun 2012-2014. Produk eksperimen itu memperlihatkan bahwa EPS dan DPS berdampak kepada nilai saham, sedangkan variabel ROI tidak berpengaruh kepada nilai saham. Di lain pihak Putra et al (2014) mengadakan penelitian berkenaan dengan pengaruh ROI, ROE, NPM, dan EPS kepada nilai penutupan saham entitas (studi pada entitas properti dan real estate yang tercatat di BEI periode 2010-2012). Produk penelitian tersebut memperlihatkan bahwa ROI dan EPS berpengaruh signifikan kepada nilai penutupan saham, sementara ROE dan NPM tidak berdampak secara signifikan kepada harga penutupan saham. Secara simultan memperlihatkan bahwa variabel ROI, EPS, ROE dan NPM memiliki pengaruh signifikan kepada harga penutupan saham. Jadi dapat ditarik sebuah hipotesis penelitian atau dugaan sementara bahwa ROI berpengaruh kepada Harga Saham.

Rasio Earnings Per Share difungsikan guna menakar kemampuan perusahaan guna meraih laba yang di inginkan oleh perusahaan. Tandelilin (2010:366 menerangkan bahwa EPS diutamakan dalam analisis perusahaan karena salah satu alasannya adalah adanya kaitan antara perubahan earnings (laba) dengan perubahan harga saham. Hal ini ditambahkan Darmadji dan Fakhrudin (2012:154) bahwa banyak calon investor tertarik pada EPS sebab merupakan salah satu indikator kesuksesan perusahaan. Berdasar tingkat kesuksesan perusahaan, para pembeli saham akan lebih menunjukkan dampaknya di waktu mendatang, sehinga pertumbuhan laba yang di laporkan perusahaan akan digunakan sebagai pertimbangan untuk para calon pembeli saham dalam 
mengambil keputusan guna berinvestasi. Peningkatan harga saham menjadi harapan besar untuk waktu mendatang dengan adanya gambaran kenaikan keuntungan dari sebuah entitas, begitu juga dengan total investasi di pasar yang akan mengikuti dalam peningkatan laba.

Gunarianto (2012) tentang Analisis Earnings Per Share (EPS), dan Return on Equity (ROE) serta tahap hubungan deposit kepada nilai saham perbankan di BEI. Hasil penelitian tersebut menunjukkan bahwa EPS dan ROE dampaknya tidak signifikan kepada harga saham, sedangkan suku bunga deposito berdampak secara signifikan kepada harga saham entitas. Sementara Putra et al (2014) melaksanakan penelitian tentang dampak ROI, ROE, NPM, dan EPS terhadap nilai penutupan saham entitas (studi pada perusahaaan properti dan real estate yang tercatat di BEI periode 2010-2012). Produk penelitian tersebut memperlihatkan bahwa ROI dan EPS berdampak signifikan kepada harga penutupan saham, sementara ROE dan NPM tidak berpengaruh secara signifikan kepada nilai penutupan saham. Secara simultan menunjukkan bahwa variabel ROI, EPS, ROE dan NPM mempunyai pengaruh signifikan kepada harga penutupan saham. Jadi penarikan hipotesis penelitian atau dugaan sementara yaitu EPS berdampak kepada Harga Saham

\section{METODE PENELITIAN}

Metode yang akan dipakai untuk pengumpulan data yaitu menggunakan teknik observasi namun teknik yang tidak langsung. Peneliti melakukan beberapa pengamatan secara langsung terhadap objek yang diteliti. Data pada penelitian ini dengan memakai teknik dokumentasi yakni dengan mengambil laporan keuangan dalam entitas manufaktur yang tercatat di Bursa Efek Indonesia (BEI) tahun 2015-2017. Perusahaan yang termaktub di Bursa Efek Indonesia (BEI) selama rentang waktu penelitian sebanyak 154 perusahaan manufaktur menjadi populasi dalam penelitian ini. Ada bermacam kriteria dalam penelitian untuk membentuk sebuah sampel penelitian, sampel penelitian memakai teknik purposive sampling. Beberapa parameter yang wajib dipenuhi guna menjadi sampel penelitian yakni 1. Perusahaan manufaktur yang mempublikasikan laporan tahunannya selama 3 tahun penenlitian. 2. Informasi yang dimiliki lengkap terkait variabel yang diteliti selama 3 tahun. 3. Perusahaan yang tidak rugi selama masa penelitian di tahun 2015 sampai 2017. Melalui proses penyortiran data dengan beberapa kriteria di atas diperoleh sampel sebanyak 56 perusahaan.

Komponen pada penelitian ini bisa dijelaskan secara operasional sebagai berikut Return On Investment (ROI) yaitu pengukuran entitas yang difungsikan guna menakar laba dari investasi yang dapat dikalkulasi berdasar jumlah pembagian dari pendapatan yang didapatkan dengan besaran aset yang ditanam. Rumus Return On Investment yakni ROI = Laba setelah pajak/total asset x $100 \%$. Earnings Per Share digambarkan sebagai pembagian keuntungan yang diberikan kepada para penanam saham yang di ukur menggunakan perbandingan laba bersih setelah pajak terhadap saham yang dilaporkan entitas. EPS yakni salah satu indikator kesuksesan entitas. Adapun rumus Earnings Per Share adalah sebagai berikut EPS = EAT/ $\mathrm{J}_{\mathrm{sb}}$. Kodrat (2010:1) menjelaskan bahwa harga saham ialah harga yang dibentuk di bursa saham dan biasanya harga saham itu didapat buat membagi jumlah nilai surat berharga. Guna menilai harga saham didalam penelitian ini berdasarkan nilai saham penutupan (Closing Price) periode 2015-2017. Adapun logaritma natural yang ditampilkan ialah Harga Saham = Ln Closing Price.

Pengumpulan data bertujuan untuk mendapatkan data penelitian dengan beberapa kriteria yang telah ditetapkan. Penelitian ini memakai pengumpulan data melalui dokumentasi. Teknik dokumentasi yakni teknik pengumpulan data dengan memperoleh data dari berbagai sumber tertulis yang kemudian ditelaah secara mendalam sehingga diperoleh data yang dibutuhkan dalam penelitian. Pengumpulan data dihasilkan dengan mengumpulkan laporan tahunan entitas tahun 2015 - 2017 yang diakses dari website Bursa Efek Indonesia dan website entitas yang menjadi sampel. Teknik analisis adalah suatu metode yang dipakai di sebuah penelitian yang untuk mengetahui hubungan sebab akibat dari variabel independen dan variabel dependen, variabel yang difungsikan pada penelitian ini ialah return on investment, earnings per share dan harga saham. Analisis regresi berganda yang akan dipakai untuk menguji variabel-variabel indenpenden dan 
dependen (Multiple Regression) pada hipotesis ke satu dan kedua. Algifari (2016:250) menyatakan bahwa "Analisis regresi berganda yaitu model regresi guna menganalisis hubungan dari dua atau lebih variabel independen terhadap satu variabel dependen".

Ada beberapa langkah dalam menganalisis regresi berganda adalah yakni a. data yang akan dianalisis dikumpulkan terlebih dahulu yakni sebagai berikut : laporan keuangan entitas manufaktur yang tercatat di BEI tahun 2015-2017. Data laporan keuangan pada penelitian ini yaitu laba sebelum pajak, total asset, laba per saham dan Harga saham penutup. b. Mengidentifikasi kekomplitan data laporan keuangan berdasar variabel yang diteliti return on investmen, earning per share, nilai saham dan mengelompokkan sesuai dengan kriteria-kriteria tertentu. c. Melakukan proses Tabulasi Microsoft Exel. Analisis data tabulasi pada dasarnya menyuguhkan data dalam wujud baris dan kolom. Data yang akan ditabulasi sesuai pada variabel yang akan diteliti yaitu return on investmen, earnings per share, dan nilai saham. d. pengujian yang dilakukan sebelum di uji hipotesis yaitu sebelumnya dilakukan uji asumsi klasik dimulai dari uji autokorelasi, uji heterokesdastisitas, uji normalitas dan uji multikolonieritas. e. Mendiskripsikan hasil data yang diperoleh dari program SPSS. f. Pengujian hipotesis guna memutuskan apakah return on investmen dan earnings per share ada pengaruh kepada harga saham. Pada umumnya model regresi berganda bisa dirumuskan dalam bentuk persamaan seperti berikut: $\mathrm{Y}=\alpha+\mathrm{b} 1$.X1 $+\mathrm{b} 2 . \mathrm{X} 2$ + e. Setelah disusun model regresi langkah selanjutnya dalam melakukan uji asumsi klasik yang terdiri atas uji normalitas, uji heterokesdastisitas, uji multikolonieritas dan uji autokorelasi.

\section{HASIL DAN PEMBAHASAN}

Pada segmen ini akan dipaparkan mengenai analisis deskriptif dari tiap-tiap variabel penelitian yang terdiri atas return on investment, earnings per share dan harga saham perusahaan. Dalam penelitian ini digunakan statistik deskriptif untuk meninjau karakteristik dari tiap sampel. Berikut adalah hasil analisis deskriptif data penelitian memakai program SPSS versi 21.0:

Tabel 1. Statistik Deskriptif

\begin{tabular}{llllll}
\hline & $\mathrm{N}$ & Minimum & Maximum & Mean & Std. Deviation \\
\hline ROI & 168 &, 00 &, 78 &, 0926 &, 09921 \\
EPS & 168 &, 20 & 2708,00 & 211,2978 & 381,10558 \\
Harga Saham & 168 & 3,91 & 11,45 & 7,1254 & 1,56215 \\
Valid N (listwise) & 168 & & & & \\
\hline
\end{tabular}

Sumber: output SPSS (data diolah), 2019

Dari tabel 1 bahwa ROI menunjukkan nilai minimum sejumlah $0 \%$, nilai maximum senilai $0,78 \%$, nilai rata-rata (mean) senilai $0,0926 \%$ dan standart deviation sejumlahr 0,09921. Nilai rata-rata (mean) lebih kecil daripada standar deviasi yakni $0,0926<0,09921$. Predikat ROI Tertinggi dimiliki Astra International Tbk dengan nilai ROI senilai 0,78\%, sedangkan predikat terendah dimiliki Jembo Cable Company Tbk dengan nilai ROI senilai 0\%. Nilai rata-rata (mean) pada tabel diatas senilai 0,0926 yang memperlihatkan bahwa pada tahun 2015-2017 entitas manufaktur sebagian besar sedang dalam posisi keuangan yang bagus.

Berdasarkan tabel 1 menunjukkan bahwa EPS mempunyai nilai minimum senilai 20, nilai maksimum senilai 2708, nilai rata-rata (mean) senilai 211,2978, dan standart deviasi senilai 381,10558. Nilai rata-rata (mean) lebih kecil dari standar deviasinya yakni 211,2978<381,10558. Predikat EPS tertinggi dimiliki Mandom Indonesia Tbk sebesar 2708, sedangkan predikat terendah dimiliki Steel Pipe Industry of Indonesia Tbk sebesar 20. Nilai rata-rata yang tercatat pada tabel sebesar 211,2978 memeperlihatkan bahwa pada tahun 2015-2017 perusahaan manufaktur sebagian besar dalam posisi keuangan yang bagus karena kadar EPS di atas Rp 100 per lembar saham. 
Berdasarkan tabel diatas menunjukkan jika harga saham mempunyai poin minimum senilai 3,91 dan poin maximum senilai 11,45 , poin rata-rata (mean) senilai 7,1254 dan standar deviasi sebesar 1,56215 . Poin rata-rata (mean) lebih besar dari standar deviasi yakni 7,1254<1,56215. Predikat harga saham teratas dimiliki oleh Hanjaya Mandala Sampoerna Tbk dan predikat terbawah dimiliki oleh Indo Acitama Tbk. Dari hasil uji asumsi klasik yang melingkupi uji normalitas, uji multikolonieritas, uji heterokesdastisitas dan uji autokorelasi.

Berdasarkan uji asumsi klasik yaitu uji normalitas, maka dapat ditunjukkan dengan memakai metode grafik normal probability plot. Grafik normal probability plot memperlihatkan sebaran titik-titik data yang tampak mengikuti arah garis dan menyebar di garis diagonal, sehingga bisa disimpulkan jika pada penelitian ini telah memenuhi kriteria untuk dilanjutkan dan layak dilakukan uji selanjutnya sesuai dengan metode penelitian diatas. Dengan menggunkan uji Kolmogorov-smirnov menunjukkan bahwa data residual terdistribusi normal. Hal ini bisa disimak pada kolom Asymp. Sig. (2-tailed) yang menunjukkan poin 0,823 yang lebih tinggi dari 0,051, sehingga menunjukkan data berdistribusi normal.

Uji multikolinearitas bertujuan guna melihat model regresi dibuktikan terdapatnya keterkaitan antara variabel bebas (variabel independen).Variabel menunjukkan terdapatnya multikonearitas jika lebih besar dari angka 10 poin VIF dan nilai tolerance kurang dari 0,1. Sedangkan jika poin VIF kurang dari 10 dan nilai tolerancen lebih tinggi dari 0,1 bahwa tidak terjadi multikolinearitas. Variabel yang diuji adalah ROI dan EPS dan dari dua variabel ini memiliki hasil kurang dari 1 untuk poin tolerance dan kurang dari 10 untuk nilai VIF. Angka yang dihasilkan yakni 0,85 untuk poin tolerance dan 1,171 untuk poin VIF.

Uji autokorelasi bermaksud guna melihat pada suatu model ini ada korelasi antara kesalahan pengganggu di periode dengan kesalahan di periode t-1 (sebelumnya). Kalau terbentuk korelasi maka disebut terjadi autokorelasi. Model regresi yang bagus merupakan regresi yang bebas autokorelasi. Autokorelasi perlu diujikan kepada regresi yang datanya menggunakan data time series contohnya diukur dalam bulanan, tahunan, dan seterusnya (Ghozali 2013). Mendeteksi autokorelasi di model regresi bisa menggunakan besaran Durbin-Watson (D-W). Berdasarkan output dengan memakai uji Durbin-Watson (DW), terlihat kalau nilai DW berada di antara $\mathrm{d}_{\mathrm{U}}$ dan $4-\mathrm{d}_{\mathrm{U}}$ yakni $1,747<2,127<2,251$ dengan begitu bisa disimpulkan kalau data penelitian ini tiada autokorelasi. Di kolom durbin-Watson dengan nilai 2,127 dengan jumlah (n) $=167, \mathrm{k}=3$ terdiri atas 2 variabel independen dan 1 variabel dependen dengan begitu didapat nilai $\mathrm{d}_{\mathrm{L}} 1,712$ dan niali $\mathrm{d}_{\mathrm{U}}$ 1,747. Nilai 4-d $\mathrm{d}_{\mathrm{U}} 2,251$ dan nilai $4-\mathrm{d}_{\mathrm{L}} 2,287$.

Uji heteroskedastisitas dilakukan guna mengukur apakah model yang digunakan mengalami ketidaksamaan varians dari residual suatu pengamatan ke pengamatan lainnya. Model regresi yang memenuhi ialah yang homokedastisitas atau tak terbentuk heteroskedastisitas. Pengujian heteroskedastisitas dilaksanakan dengan memakai Scater Plot dan uji glejser. Pengujian menggunakan Scater Plot dapat disimak dari penyebaran titik-titik yang ditimbulkan tak menciptakan sebuah pola atau alur tertentu disebut tidak terjadi heteroskedastisitas. Sedangkan pengujian menggunakan uji glejser dapat dilihat dari nilai signifikansinya lebih dari 0,05 disebut tak terjadi heteroskedastisitas. Setelah semua uji asumsi regresi terpenuhi, maka pengujian yang digunakan selanjutnya ialah analisis regresi linier berganda yang berguna guna menunjukkah pengaruh variabel independen (return on investment dan earning per share) kepada variabel dependen (harga saham). Analisis statistik dilakukan dengan memakai program Microsofl excel dan program SPSS 21. Ada beberapa tahap untuk pengolahan data yaitu dengan memfungsikan analisis regresi linier berganda yang bisa dilihat persamaan dari regresi linier berganda bisa dirumuskan yakni $\mathrm{Y}=\alpha+\mathrm{b}_{1} \mathrm{X}_{1}+\mathrm{b}_{2} \mathrm{X}_{2}+\mathrm{e}$. 
Berdasar hasil pensgolahan data dengan memakai SPSS 21 bisa ditunjukkan dalam tabel berikut:

Tabel 1. Uji Regresi Linier Berganda

\begin{tabular}{|c|c|c|c|c|c|c|}
\hline \multicolumn{2}{|c|}{ Model } & \multicolumn{2}{|c|}{$\begin{array}{l}\text { Unstandardized } \\
\text { Coefficients }\end{array}$} & \multirow{2}{*}{$\begin{array}{l}\text { Standardized } \\
\text { Coefficients } \\
\text { Beta }\end{array}$} & \multirow[t]{2}{*}{$\mathrm{T}$} & \multirow[t]{2}{*}{ Sig } \\
\hline & & B & Std. Error & & & \\
\hline \multirow[t]{3}{*}{1} & (constant) & 6,230 & , 125 & & 49,765 & ,000 \\
\hline & ROI (X1) & 5,395 & ,988 & ,343 & 5,462 & ,000 \\
\hline & EPS (X2) & ,002 & ,000 & ,456 & 7,275 & ,000 \\
\hline
\end{tabular}

Sumber: Output SPSS (Data diolah), 2019

Berdasar hasil uji model regresi linier berganda dengan persamaan regresi yang dihasilkan yaitu $\mathrm{Y}=6,230+5,396 \mathrm{x}_{1}+0,002 \mathrm{x}_{2}+\mathrm{e}$. Berdasarkan uji yang dilakukan dapat dihasilkan nilai koefisien regresi ROI senilai 5.396, kondisi ini menunjukkan dimana setiap kenaikan 1 ROI akan menimbulkan kenaikan terhadap harga saham senilai 5,396 dan nilai koefisien regresi EPS senilai 0,002, ihwal ini memperlihatkan jika setiap kenaikan EPS 1 maka akan menaikkan harga saham senilai 0,002. Untuk hasil uji akan diterangkan sebagai berikut: $\mathrm{H}_{1}$ : pengaruh ROI terhadap harga saham. Pengujian hipotesis 1 menunjukkan dimana ROI berpengaruh kepada nilai saham. Kondisi ini diketahui dalam tabel uji koefisien regresi linier berganda di atas dimana untuk variabel ROI memperlihatkan nilai sig sejumlah 0,000 nilai ini lebih rendah dari $\alpha=0,05$ yang memperlihatkan variabel ROI berpengaruh kepada nilai saham. $\mathrm{H}_{2}$ : pengaruh EPS terhadap nilai saham. Pengujian hipotesis 2 memperlihatkan bahwa EPS berimbas kepada nilai saham. Kondisi ini diperlihatkan dalam tabel uji koefisien regresi linier berganda di atas dimana untuk variabel EPS memperlihatkan nilai sig sejumlah 0,000 nilai ini lebih rendah dari $\alpha=0,05$ yang memperlihatkan variabel EPS berimbas kepada harga saham.

Berdasar hasil uji hipotesis yang membuktikan bahwan $R O I$ memiliki pengaruh kepada harga saham. Produk penelitian seiring dengan penelitian terdahulu yang menyatakan return on investment berimbas kepada harga saham. Rasio ini menunjukkan sebuah kondisi suatu perusahaan yang dapat memaksimalkan penggunaan aset untuk menghasilkan keuntungan dapat dilakukan dengan cara menaikkan nilai perusahaan berupa peningkatan harga saham karena saham dapat menjadi sebuah pertimbangan utama oleh investor, sehingga return on investment bias difungsikan investor sebagai referensi guna menentukan keputusan. Hasil ini berbeda dengan maklumat Brigham dan Houston (2013:148) ROI yang kecil belum tentu buruk, hal ini bisa terjadi karena manajer memutuskan untuk memakai utang dalam nilai yang tinggi, beban bunga yang besar megakibatkan keuntungan bersih menjadi relatif kecil. Meskipun ROI mengalami perubahan dari yang rendah atau tinggi tetap tidak mempengaruhi harga saham.

Dari hasil ini akan membuktikan bahwa kinerja entitas dalam mengelola seluruh asset guna mendapatkan keuntungan sangat optimal. Maka, reputasi entitas baik dilhat dari kinerja ROI yang semakin tinggi. Investor akan berpikir ulang ketika ingin berinvestasi atau menanamkan sahamnya ke perushaan yang memiliki kondisi yang baik dari segi pengelolaan keuangannya dengan ROI yang semakin tinggi menunjukkan perusahaan itu aman dan ada pengharapan dalam memperoleh keuntungan, dengan hal tersebut maka nilai saham juga akan meningkat. Jadi dapat disimpulkan apabila ROI berpengaruh positif dalam pemakaian dan pengelolaan asset entitas yang optimal bahwa akan meningkatkan nilai ROI dan nilai saham entitas dan apabila ROI berpengaruh negatif artinya kalau ROI naik dan harga penutupan saham turun karena laba yang didapatkan investor atas kenaikan ROI terkadang dengan sebuah pilihan yaitu digunakan untuk kegiatan mengelola aset dan pelunasan hutang entitas sehingga deviden tidak dibagikan. 
Berdasarkan hasil uji menunjukkan bahwa Earnings per share (EPS) berimbas kepada nilai saham. Makin besar EPS maka makin tinggi kapasitas perusahaan dalam memberikan deviden pada investor yang berbanding lurus dengan tingkat pengembalian yang akan diperoleh investor. Earnings per share atau laba per lembar saham menjadi amat penting untuk setiap pemegang saham sebab tingkat profit yang didapat dilihat dalam rasio ini. Hal ini terbukti jika Earnings per share merupakan dasar suatu entitas yang berimbas kepada nilai saham sebab investor melihat pertumbuhan nilai EPS untuk mengambil keputusan sebagai acuan dalam menentukan tingkat harga sebuah sebuah perusahaan. Banyak pertimbangan bagi investor untuk membeli saham daris ebuah entitas tertentu yaitu dengan melihat apakah entitas tersebut mampu memperoleh laba yang ebsar untuk menarik minat para investor, sebab investor lebih condong berpikir ulang guna membeli saham ketika EPS yang ditunjukkan entitas tertentu mengalami penuruna, namun jika mengalami kenaikan maka tidak sedikit investor yang akan tertarik membeli saham pada entitas tersebut. Jadi dapat disimpulkan jika EPS adalah komponen yang esensial yang wajib dicermati oleh setiap penanam modal sebab EPS merupakan pendapatan yang didapat dari setiap entitas.

\section{KESIMPULAN}

Rasio ini menunjukkan sebuah kondisi suatu perusahaan yang dapat dipakai untuk memaksimalkan penggunaan asset suatu perusahaan dalam menghasilkan keuntungan nilai perusahaan jika ditingkatkan maka peningkatan terhadap harga saham karena mendapat respon yang baik oleh investor, sehingga investor bisa menggunakan return on investment sebagai salah satu pertimbangan. Salah satu faktor lagi yang berpengaruh yaitu earnings per share atau laba per lembar saham bermanfaat untuk setiap calon penanam modal karena rasio ini dapat menerminkan besar kecilnya keuntungan yang akan mereka dapatkan.

Peneliti memiliki sejumlah kekurangan dalam melakukan penelitian, diantaranya: 1) Penelitian ini hanya menguji faktor internal yaitu Return on Investment (ROI) dan Earning per Share (EPS) sehingga peneliti membatasi menguji faktor internal lainnya dan faktor eksternal yang berpengaruh terhadap harga saham. 2) Sampel penelitian yang terbatas karena tidak semua perusahaan yang membagikan dividen selama tahun penelitian. 3) periode penelitian hanya tiga tahun terakhir yakni periode penelitian dengan begitu kurang menggambarkan kondisi pasar modal yang seutuhnya. Bagi peneliti selanjutnya, diharapkan untuk meningkatkan jumlah variabel yang berhubungan dengan harga saham, memperkuat jurnal dan referensi. Bagi perusahaan, Bagi investor yang ingin berinvestasi sebaiknya lebih teliti lagi melihat kinerja keungan perusahaan berdasarkan analisis rasio keuangannya.

\section{DAFTAR PUSTAKA}

Algifari. (2016). Statistika Induktif Untuk Ekonomi Dan Bisnis (Edisi 3). Yogyakarta: UPP STIM YKPN.

Aminah, N., Afifati, R., \& Supriyanto, A. (2016). Pengaruh Deviden Per Share, Return On Equity, Net Profit Margin, Return On Investment dan Return On Asset Terhadap Harga Saham Pada Perusahaan Real Estate dan Property Yang Terdaftar Di Bursa Efek Indonesia Periode Tahun 2011-2013. Accounting, 2(2), 1-19. Diperoleh pada 15 januari 2019, dari https://Doi.Org/10.1111/Jgh.14027

Brigham dan Houston. (2010). Dasar-Dasar Manajemen Keuangan Buku 1 (Edisi 11). Jakarta: Salemba Empat.

Brigham, E. F, dan Houston, J. F. 2009. Dasar-dasar Manajemen Keuangan. Diterjemahkan Oleh Ali Akbar Yulianto. Buku 1 Edisi 11. Jakarta: Salemba Empat.

Darmaji, T \& Fakharudin, H. (2012). Pasar Modal Di Indonesia. Jakarta: Salemba Empat.

Fahmi, I. (2013). Rahasia Saham Dan Obligasi Strategi Meraih Keuntungan Tak Terbatas Dalam Bermain Saham Dan Obligasi. Bandung: ALFABETA.

Ghozali, I. (2016). Aplikasi Analisis Multivariate Dengan Program IBM SPSS 23. Semarang: Badan Penerbit Universitas Diponegoro. 
Gunarianto. (2012). Analisis Earning Per Share Dan Return On Equity Serta Tingkat Bunga Deposito Terhadap Harga Saham Perbankan Di Bursa Efek Indonesia. Jurnal Manajemen Dan Akuntansi, 1(2), 31-42. Diperoleh pada 28 Desember 2018, dari

Hadi, N. (2015). Pasar Modal (Edisi 2). Yogyakarta: Graha Ilmu.

Halim, A. (2015). Analisis Investasi Di Aset Keuangan (Edisi 1). Jakarta: Mitra Wacana Media.

Harahap, S. S. (2016). Analisis Kritis Atas Laporan Keuangan (Edisi Ke 1). Jakarta: Rajawali Pers.

Harjito, A. (2009). Keuangan Keperilakuan Menganalisis Keputusan Investor (Edisi 8). Yogyakarta: BPEF Yogyakarta.

Hermuningsih, S. (2012). Pengantar Pasar Modal Indonesia. Yogyakarta.: UPP STIM YKPN.

Indrawan, R \& Yuniawati, P. (2014). Metode Penelitian Kuantitatif, Kualitatif, Campuran Untuk Manajemen, Pembangunan, dan Pendidikan. Bandung: PT. RefikaAditama.

Isyani, C. P. M. (2015). Pengaruh Return Oninvestment (ROI) dan Earning Per Share (EPS) Terhadap Harga Saham Perusahaan dengan Memperhatikan Perceived Risksaham Sebagai Variabel Moderasi (Studi Pada Perusahaan Manufaktur Yang Terdaftar Di Bursa Efek Indonesia Tahun 2011-2013). Diperoleh pada 25 Desember 2018, dari

Januar, S. (2018). Pengaruh ROI, ROE, MVA dan EPS Terhadap Harga Saham Pada Perusahaan Kategori LQ-45 Pada Bursa Efek Indonesia 2013 - 2015. Diperoleh pada 13 Januari 2019, dari

Jayanti, E. D. W. I., Tinggi, S., \& Ekonomi, I. (2015). Pengaruh Return On Investment (ROI), Earning Per Share (EPS), dan Price Earning Ratio (PER) Terhadap Harga Saham Perusahaan Pertambangan Yang Terdaftar Di BEI Tahun 2011-2013. Diperoleh pada 13 Januari 2019.

Jogiyanto. (2008). Teori Portofolio Dan Analisis Investasi. Yogyakarta: BPEF Yogyakarta.

Kasmir. (2016). Laporan Keuangan (Edisi 1 Ce). Jakarta: Rajawali Pers.

Kodrat, D. S. K. I. (2010). Manajemen Investasi Pendekatan Teknikal Dan Fundamental Untuk Analisis Saham. Yogyakarta: Graha Ilmu.

Munawir, S. (2010). Analisis laporan keuangan (Edisi keem). Yogyakarta: Liberty.

Nursetyo, R., \& Wahid, A. (2016). Pengaruh Return On Investment (ROI) dan Earnings Per Share (EPS) Terhadap Harga Saham Perusahaan Dengan Perceived Risk Saham Sebagai Variabel Moderasi (Studi Pada Perusahaan Manufaktur Yang Terdaftar Di Bursa Efek Inonesia Tahun 2013-2016).O Title, 105-126.Diperoleh pada 25 Desember 2018.

Paramita, R. W. D. (2015). Metode Penelitian Kuantitatif (Edisi 1). Lumajang: STIE WIDYAGAMA LUMAJANG.

Prastowo, D. (2015). Analisis Laporan Keuangan Konsep Dan Aplikasi (Edisi 1). Yogyakarta: UPP STIM YKPN.

Priantinah, D., \& Kusum, P. A.. (2012). Pengaruh Return On Investment(ROI), Earning Per Share (EPS), dan Deviden Per Share (DPS)Terhadap Harga Saham Perusahaan Pertambangan Yang Terdaftar Di Bursa Efek Indonesia (Bei) Periode 2008-2010. Value Added, 1(1), 118. Diperoleh pada 25 Desember 2018, dari Https://Doi.Org/10.1007/S13398-014-0173-7.2

Putra, Y. P., \& Rahayu, S. M. (2014). Pengaruh Return On Investmen, Return On Equity , Net Profit Margin, dan Earning Per Share Terhadap Harga Penutupan Saham Perusahaan ( Studi Pada Perusahaan Properti Dan Real Estate Yang Terdaftar Di BEI, 8(2), 1-7. Diperoleh pada 25 Desember 2018.

Rodiyah, W. A., Sulasmiyati, S.. (2016). PENGARUH Return On Investment ( ROI ), Return On Equity ( ROE ), Earning Per Share (EPS ) Dan Economic Value Added ( EVA ) Terhadap Harga Saham ( Studi Pada Perusahaan Sub Sektor Property Dan Real Estate Yang Terdaftar Di Bursa Efek Indonesia ( BEI ) Per, 59(1). Diperoleh pada 15 Januari 2019.

Standar Akuntansi Keuangan Per Efektif 1 Januari 2015. (2014). Jakarta: Ikatan Akuntansi Indonesia.

Sudana, I. M. (2011). Manajemen Keuangan Perusahaan Teori Dan Praktik. Jakarta: Erlangga.

Sugiyono. (2014). Metode Penelitian Kuantitatif, Kualitatif, R\&D. Bandung: ALFABETA.

Sunariyah. (2011). Pengantar Pengetahuan Pasar Modal. Yogyakarta: YKPN. 
Sunyoto, D. (2013). Analisis Laporan Keuangan Untuk Bisnis (Teori Dan Kasus). Yogyakarta: CAPS.

Syahyunan. (2013). Manajemen Keuangan: Perencanaan, Analisis, dan Pengendalian Keuangan. Medan: USU Press.

Tejaningtyas, S. R., \& Tejaningtyas, S. R. (2016). Analisis Pengaruh Rasio Profitabilitas Terhadap Harga Saham Pada Perusahaan Real Estate dan Property Yang Terdaftar Di Bursa Efek Indonesia Tahun 2012-2014, 2(2), 145-165. Diperoleh pada 25 Desember 2018.

Tendelilin, E. (2010). Portfolio dan investasi teori dan aplikasi (Edisi Pertama). Yogyakarta: Kanisius.

Utari, Dewi, Dkk. (2014). Manajemen Keuangan Edisi Revisi. Jakarta: Mitra Wacana Media. . (2014). Rahasia Saham Dan Obligasi Strategi Meraih Keuntungan Tak Terbatas Dalam Bermain Saham Dan Obligasi. Bandung: ALFABETA.

. (2015). Manajemen Investasi:Teori Dan Soal Jawaban (Edisi 2). Jakarta: Salemba Empat. . (2017). Pengantar Pasar Modal. Bandung: ALFABETA.

www.IDX.co.id 